\title{
CELL TECHNOLOGIES IN BIOLOGY AND MEDICINE
}

\section{Proteomic Profiling of HL-60 Cells during ATRA-Induced Differentiation}

\author{
I. V. Vakhrushev, S. E. Novikova, A. V. Tsvetkova, P. A. Karalkin, \\ M. A. Pyatnitskii, V. G. Zgoda, and K. N. Yarygin
}

Translated from Kletochnye Tekhnologii v Biologii i Meditsine, No. 2, pp. 71-85, June, 2018

Original article submitted April 3, 2018

\begin{abstract}
Acute promyelocytic leukemia, a form of acute myeloid leukemia, is characterized by cell differentiation arrest at the promyelocyte stage. Current therapeutic options include administration of all trans-retinoic acid (ATRA), but this treatment produces many side effects. ATRA is known to induce differentiation of leukemic cells into granulocytes, but the mechanism of this process is poorly studied. We performed comparative proteomic profiling of HL-60 promyelocytic cells at different stages of ATRA-induced differentiation to identify differentially expressed proteins by high-resolution mass spectrometry and relative quantitative analysis without isotope labels. A total of 1162 proteins identified by at least two unique peptides were analyzed, among them 46 and 172 differentially expressed proteins were identified in the nuclear and cytosol fractions, respectively. These differentially expressed proteins can represent candidate targets for combination therapy of acute promyelocytic leukemia.
\end{abstract}

Key Words: acute promyelocytic leukemia; trans-retinoic acid; targeted therapy

At the time of the first description of the nosological entity in 1950s, acute promyelocytic leukemia (OPL) was characterized by high mortality rate, primary due to hemorrhagic complications. The median survival was less than 1 week. The disease poorly responded to treatment: the first available therapy with 6-mercaptopurine led to remission in only $5-14 \%$ patients; introduction of anthracyclines (including daunorubicin) made it possible to increase the probability of remission to $58 \%$ [4]. Discovery of differentiation-inducing effect of all trans-retinoic acid (ATRA) on leukemic cells and introduction of differentiating therapy into clinical practice made a revolution in the treatment of OPL and led to an increase in 5-year complete remission rate to $85 \%$ [23]. The main complications

V. N. Orekhovich Research Institute of Biomedical Chemistry, Moscow, Russia. Address for correspondence: vakhrunya@gmail.com. I. V. Vakhrushev. of ATRA monotherapy is the development of drug resistance and the risk of severe side effect, so-called differentiation syndrome or retinoic acid syndrome. In some cases, a good clinical result can be achieved due to combination of ATRA with other drugs, such as arsenic trioxide and idarubicin $[8,10]$. This combination therapy allows reducing the dose of ATRA and, consequently, the risk of complications and side effects associated with differential therapy. Thus, the search for new ATRA agonists is an urgent problem of modern oncology.

The search for new potential targets of tumor therapy is a laborious process and screening of potential regulators of biological processes such as differentiation and proliferation is a very important step in this process. Proteomic approaches, primarily mass spectrometry, are a suitable tool in detection of molecules involved in the realization of cell fate and having therapeutic potential $[1,3,26]$. Regulatory molecules, 
such as cell receptors (e.g. c-kit [12]) and molecules of signal pathways, e.g. mammalian target of rapamycin (mTOR)-mediated autophagy pathway, are generally considered among potential targets [11]. Many differentiation-related molecules, including transcription factors acting as biological signaling end-points, are located in the cell nucleus. In light of this, it seems interesting to study the dynamics of nucleus proteome of OPL cells in response to treatment with differentiation inducer ATRA.

Our aim was to identify nuclear proteins, whose content changes during ATRA-induced granulocyte differentiation of HL-60 cells, and that can serve as potential targets of combined therapy of promyelocytic leukemia. HL-60 promyelocytic leukemia cell line was chosen as the model because these cells differentiate into mature granulocytes under the action of ATRA $[12,18]$.

\section{MATERIALS AND METHODS}

Cell cultures. Cell culture line HL-60 were obtained from the Cryobank of the V. N. Orekhovich Research Institute of Biomedical Chemistry. After defrosting, the cells were cultured in RPMI-1640 growth medium with $10 \%$ fetal calf serum, $100 \mathrm{U} / \mathrm{ml}$ penicillin, $100 \mathrm{U} /$ $\mathrm{ml}$ streptomycin, and $2 \mathrm{mM} \mathrm{L}$-glutamine (all reagents were from Gibco) in a $\mathrm{CO}_{2}$ incubator under standard conditions $\left(37^{\circ} \mathrm{C}, 5 \% \mathrm{CO}_{2}, 80 \%\right.$ humidity). After attaining cell concentration of $10^{6}$ cells $/ \mathrm{ml}$ culture, the cells were subcultured at a ratio of 1:3. The cells were counted in a Goryaev's chamber.

MTT test. The sensitivity of HL-60 cells to ATRA was evaluated by the effect of the agent on their proliferative activity. After centrifugation, the cells were resuspended in growth medium to a concentration of $106 / \mathrm{ml}$ and transferred to wells of 24-well flat-bottom plate $(1 \mathrm{ml}$ per well). In $2 \mathrm{~h}$ after cell seeding into the wells, $1 \mathrm{ml}$ growth medium containing ATRA (Sigma) in concentrations of $200,180,160,140,120,110,100$, $80,60,40,20$, and $2 \mu \mathrm{M}$ was added so that the final concentration of ATRA was $100,90,80,70,60,50$, $40,30,20,10$, or $1 \mu \mathrm{M}$. In the control group, $1 \mathrm{ml}$ growth medium was added.

The cells were incubated under standard conditions for $96 \mathrm{~h}$, then, $200 \mu \mathrm{l}$ of aqueous solution of MTT (Sigma) in a concentration of $5 \mathrm{mg} / \mathrm{ml}$ (final concentration $0.5 \mathrm{mg} / \mathrm{ml}$ ) was added to each well and the plates were placed in the incubator for $3 \mathrm{~h}$. After incubation, the content of the wells was carefully collected, transferred into Eppendorf test tubes, and centrifuged in a table centrifuge. Then, the supernatant was gently removed from the tubes, $100 \mu \mathrm{DMSO}$ (PanEco) was added, and the tubes were vortexed until the precipitate was fully dissolved. Optical density of the resultant solution was measured on an Infinite $200 \mathrm{PRO}$ plate reader (Tecan) at $\lambda=550 \mathrm{~nm}$ (reference measurements were made at $\lambda=690 \mathrm{~nm}$ ). Proliferative activity of cells was calculated by the formula D2/ D $1 \times 100 \%$, where D1 and D2 are optical densities corresponding to cell number before and after incubation with ATRA, respectively.

Flow cytofluorometry. Expression of surface markers on cells was analyzed by flow cytofluorometry. To this end, the cells were precipitated by centrifugation and resuspended in $1 \mathrm{ml}$ PBS with $1 \%$ fetal calf serum (Gibco) and $0.1 \% \mathrm{NaN}_{3}$ (Sigma) to cell concentration of $10^{6} / \mathrm{ml}$; the washout procedure was repeated three times. Finally, the cells resuspended in $0.1 \mathrm{ml}$ of the same solution were incubated at $4^{\circ} \mathrm{C}$ for $60 \mathrm{~min}$ with $10 \mu \mathrm{l}$ monoclonal antibodies directly labeled with phycoerythrin (Becton Dickinson); phycoerythrin-labeled isotypic antibodies (Becton Dickinson) served as the negative control. After precipitation and washing, the cells were resuspended in $0.25 \mathrm{ml}$ of the above buffer and fixed in $0.25 \mathrm{ml} 4 \%$ paraformaldehyde over $4 \mathrm{~min}$ at room temperature. Then, the cell suspension was brought to $1 \mathrm{ml}$ with buffer and filtered to remove cell aggregates (30 $\mu$-pore filter).

Analysis was performed on FACSAria III cytofluorometer sorter (Becton Dickinson). The instrument was operated and the primary data were analyzed using FACSDiva software.

Marker expression was evaluated by the fluorescence intensity histogram of the label conjugated with specific monoclonal antibodies. Ten thousand events were recorded at minimum cell suspension flow rate. To exclude noise and objects less than cells, the registration threshold for direct light scattering was set at 20,000 .

Further analysis of experimental data was performed using FlowJo software. To compare fluorescence intensity of the test sample and isotypical control, the results of experimental sample and control were superimposed in the histogram mode.

Preparation of samples for proteomic analysis. HL-60 cells in the growth medium were placed in $75-\mathrm{cm}^{2}$ culture flasks (cell concentration 106/ml, $10 \mathrm{ml}$ medium), and $5 \mathrm{ml}$ growth medium containing ATRA in a concentration of $150 \mu \mathrm{M}$ (final concentration $50 \mu \mathrm{M}$ ) was added, and the flasks were incubated in a $\mathrm{CO}_{2}$ incubator under standard conditions for 3, 24, or $96^{2} \mathrm{~h}$. After incubation, the cells were washed three times by centrifugation/resuspension in $10 \mathrm{ml}$ PBS and the tubes with cell pellet were frozen in liquid nitrogen. The cells cultured without ATRA were used as the control corresponding to time point 0 .

Lysis of cells and isolation of nuclear fraction. Nuclear fraction proteins were isolated by chemical extraction [16]. Tubes with HL-60 cell pellet were 
thawed, $300 \mu \mathrm{l}$ cold lysing buffer containing $10 \mathrm{mM}$ HEPES-NaOH (pH 7.9), $1.5 \mathrm{mM} \mathrm{MgCl}, 10 \mathrm{mM} \mathrm{KCl}$, $0.5 \%$ NP-40, $0.1 \mathrm{mM}$ EDTA, and complete protease inhibitor cocktail (Roche) was added, the tubes were incubated for $15 \mathrm{~min}$ on ice and centrifuged for $10 \mathrm{~min}$ $(6000 \mathrm{rpm})$ at $4^{\circ} \mathrm{C}$. The supernatant containing the cytosolic fraction was collected and stored for further analysis. The obtained pellet containing nuclei was washed twice with lysing buffer without NP-40. For isolation of nuclear fraction, extraction buffer containing $20 \mathrm{mM}$ HEPES-NaOH ( $\mathrm{pH} 7.9$ ), $25 \%$ glycerol, $1.5 \mathrm{mM} \mathrm{MgCl}_{2}$, $420 \mathrm{mM} \mathrm{NaCl}, 0.1 \mathrm{mM}$ EDTA, and protease inhibitor cocktail (Roche) was added, the tubes were incubated for $30 \mathrm{~min}$ on ice and centrifuged for $10 \mathrm{~min}(6000$ $\mathrm{rpm})$. The supernatant containing the nuclear fraction was collected and stored for further analysis.

Total protein concentration in samples of each fraction was measured by the colorimetric method with bicinchonic acid (BCA) using commercial Pierce BCA Protein Assay Kit (Pierce) according to manufacturer's recommendations.

Preparation of cytosolic and nuclear fraction proteins for mass spectrometric analysis. Hydrolysis of proteins was carried out according to FASP Protocol (Filter-Aided Sample Preparation) [24]. Protein mixture aliquots $(100 \mu \mathrm{g})$ were placed in YM-10 Microcon device concentrating filters (Millipore). The samples were washed by adding $200 \mu \mathrm{l}$ buffer containing $8 \mathrm{M}$ urea with addition of $100 \mathrm{mM}$ tris $\mathrm{HCl}$ (pH 8.5) followed by centrifugation at $11,000 \mathrm{~g}$ for 15 min at $20^{\circ} \mathrm{C}$. The washing procedure was repeated 3 times. The samples were then alkylated. To this end, the material was placed in concentrating filters, $100 \mu 1$ alkylating solution containing $50 \mathrm{mM}$ iodacetamide was added, the mixture was incubated for $30 \mathrm{~min}$ at $25^{\circ} \mathrm{C}$ with shaking $(600 \mathrm{rpm})$, and then precipitated for $15 \mathrm{~min}$ at $20^{\circ} \mathrm{C}$. After alkylation, the samples were washed twice with $200 \mu \mathrm{l}$ buffer followed by centrifugation at $11,000 \mathrm{~g}$ for $40 \mathrm{~min}$ at $20^{\circ} \mathrm{C}$. To samples in concentrating filters, $40 \mu \mathrm{l}$ buffer for trypsinolysis containing $100 \mathrm{mM}$ solution of tetraethylammonium bicarbonate ( $\mathrm{pH} \mathrm{8.5)}$; then, trypsin solution was added to each sample (total weight of the enzyme/total mass protein weight $1: 100$ and incubated fovernight at $37^{\circ} \mathrm{C}$.

After incubation with the enzyme, peptide samples were centrifuged at $11,000 \mathrm{~g}$ and $20^{\circ} \mathrm{C}$ for $15 \mathrm{~min}$ and the filtrate was collected. The filters were then washed with $30 \%$ formic acid by centrifugation at $11,000 \mathrm{~g}$ and $20^{\circ} \mathrm{C}$ for $15 \mathrm{~min}$ and the filtrates were also collected. The peptide mixtures obtained for the cytosol and nuclear fractions was lyophilized on a rotary concentrator and dissolved in $100 \mu 10.1 \%$ formic acid. The resultant samples were analyzed by mass spectrometry.

Liquid chromatography mass spectrometry. Liquid chromatography mass spectrometry was per- formed for each experimental time point in 5 technical repeats. The peptide mixture was applied on concentrating Zorbax 300SB-C18 column $(5 \mathrm{~mm} \times 0.3 \mathrm{~mm}$; particle diameter $5 \mu$; Agilent Technologies) and mobile phase $\mathrm{C}$ for concentration column loading and washout $(5 \%$ acetonitrile in $0.1 \%$ formic acid and $0.05 \%$ trifluoroacetic acid) was supplied at a flow rate of $3 \mu \mathrm{l} / \mathrm{min}$ over $5 \mathrm{~min}$. The peptides were separated on a Zorbax 300SB-C18 analytical column (3.5 $\mu$, $150 \mathrm{~mm} \times 75 \mu$; Agilent Technologies) using mobile phase B gradient $(80 \%$ acetonitrile in $0.1 \%$ formic acid) at a flow rate of $0.3 \mu \mathrm{l} / \mathrm{min}$. The following parameters of acetonitrile gradient were used: the analytical column was washed with mobile $5 \%$ phase B for $5 \mathrm{~min}$, after which the concentration of mobile phase B was linearly increased to $60 \%$ over $80 \mathrm{~min}$ and to $100 \%$ over the next $5 \mathrm{~min}$; then, the analytical column was washed with $100 \%$ mobile phase B for 10 min, after which the concentration of mobile phase B was reduced to $5 \%$ over $5 \mathrm{~min}$, and during the next $15 \mathrm{~min}$, the analytical column was equilibrated with $5 \%$ mobile phase $\mathrm{B}$.

Mass spectrometry was performed on an Orbitrap Velos hybrid mass spectrometer (Thermo Fisher Scientific) with orbitrap mass analyzer. The maximum time of accumulation of $10^{6}$ ions for MC-scanning with resolution of 30,000 (for $\mathrm{m} / \mathrm{z}=400$ ) in the $\mathrm{m} / \mathrm{z}$ range of 300-2000 in the positive ionization mode was $50 \mathrm{msec}$. Five most intense ions recorded in the MS-scan were selected for further fragmentation, if their absolute intensity exceeded 5000 rel. units. HCD fragmentation mode with normalized collision energy of $35 \%$ was used. Dynamic exclusion from tandem analysis was applied: the duration of exclusion was $90 \mathrm{sec}$ after the ion was fragmented at least once and MS/ MS-spectrum was acquired over $30 \mathrm{sec}$. The list of exclusion consisted of 500 ions. The maximum time of accumulation of $5 \times 10^{4}$ ions for MS/MS-scan acquisition with resolution of 7500 (for $\mathrm{m} / \mathrm{z}=400$ ) in the $\mathrm{m} / \mathrm{z}$ range of 300-2000 in the positive ionization mode was $100 \mathrm{msec}$.

The recorded mass spectrometric data were processed using MaxQuant 1.5.5.0 (Max Planck Institute of Biochemistry).

Protein identification and relative quantitative analysis based on the area under the peak of the parent precursor ion. The proteins were identified using MaxQuant 1.5.5.0 software with Andromeda algorithm, FASTA file containing amino acid sequences of human proteins (29-03-2016), and FASTA file with inverted sequences to calculate the frequency of false positive identification (FDR). Carbamidomethylation of cysteine and oxidation of methionine were used as fixed and variable modifications, respectively. The tolerance for parent and daughter ions was $20 \mathrm{ppm}$. 
For proteins and peptides, the threshold FDR was set at 0.01 .

The quantitative analysis was carried out on the basis of area under the peak of the parent ion with calculation of LFQ (label-free quantification intensity) using built-in MaxQuant algorithm [5]. Statistical analysis was performed using Perseus 1.6.0.7 software (Max Planck Institute of Biochemistry). Mass spectrometry data for all experimental points $(0,3,24$, and $96 \mathrm{~h}$ ) were compared. In addition, the data obtained at the experimental points 3,24 , and $96 \mathrm{~h}$ were pairwise compared with the control point $0 \mathrm{~h}$. Heat maps reflecting changes in the expression of genes of proteins differentially expressed throughout the differentiation period were constructed.

The functional annotation was performed using GeneOntology Biological Process module and geneXplain platform software. Functional annotation groups containing at least 20 proteins $(p<0.005)$ for the cytosol fraction and 7 proteins $(p<0.005)$ for the nuclear fraction were considered.

\section{RESULTS}

Effect of ATRA on cell proliferation. The effect of ATRA on proliferation of HL-60 cells was assessed using MTT test based on the ability of mitochondrial dehydrogenases in live, but not dead cells to convert water-soluble yellow MTT into insoluble purple-blue intracellular crystals of MTT-formazan. As optical density (D) at 540-570 $\mathrm{nm}$ of formazan dissolved in DMSO is proportional to the number of viable cells $(n)$, MTT-test can be used to assess viability and proliferation of cell cultures in situ [7].

First, we studied the effect of ATRA on proliferative activity of HL-60 cells (Fig. 1). It was found that the presence of low concentrations of ATRA (1-30 $\mathrm{mM})$ in the medium did not affect cell proliferation. After increasing ATRA concentration above $30 \mu \mathrm{M}$, the number of viable cells decreased and reached minimum at ATRA concentration of $70 \mu \mathrm{M}$. ATRA in concentrations of $70 \mu \mathrm{M}$ produced a pronounced cytotoxic effect; no viable cells were found in these cases. It is known that HL-60 cells lose proliferation capacity after differentiation into granulocytes. Thus, our primary task was to determine the concentration of ATRA that inhibited cell proliferation, but did not produce pronounced cytotoxic effect. Our findings suggest that ATRA in our experimental model was most effective in a concentration of $50 \mu \mathrm{M}$, because the number of viable cells in this case remained almost unchanged over $96 \mathrm{~h}$ of the experiment.

Changes in the expression of CD11b and CD14 in HL-60 cells under the influence of ATRA. To confirm that ATRA in a concentration of $50 \mu \mathrm{M}$

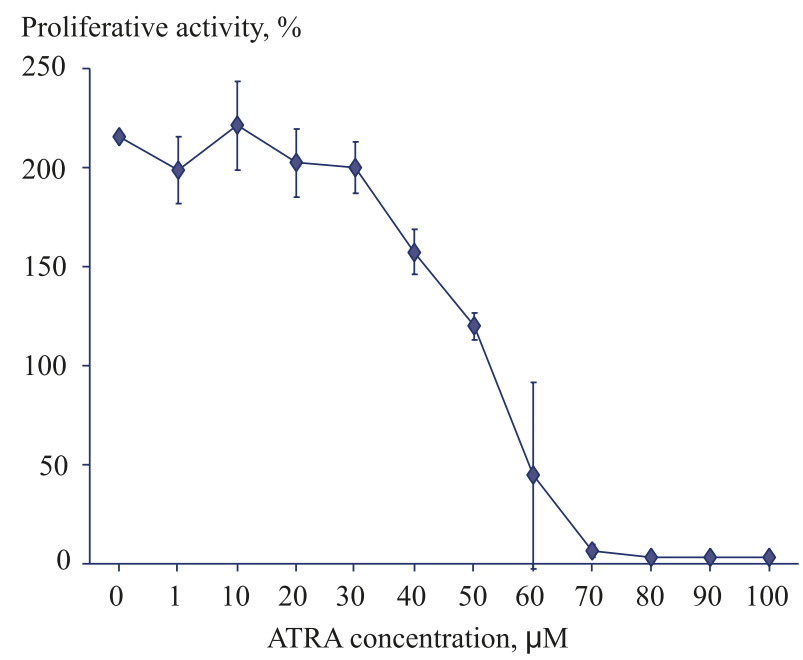

Fig. 1. Effect of different ATRA concentrations on proliferation of HL-60 cells.

does induce differentiation of HL-60 cells, we studied changes in the expression of CD11b and CD14 marker molecules on their surface under the influence of ATRA (Fig. 2). Simultaneous expression of CD11b (complement receptor 3) and CD14 (a component of the receptor complex CD14/TLR4/MD2 recognizing LPS) is a characteristic feature of mature granulocytes. Unlike native cells, cells cultured in a medium with $50 \mu \mathrm{M}$ ATRA demonstrated high expression of these markers, which indicated their differentiation towards granulocytes [17].

Changes in proteome of HL-60 cells during ATRA-induced differentiation. In the proteomic analysis of HL-60 cells at different stages of granulocytic differentiation, nuclear proteins are particular interest, because this particular compartment functions as a regulatory center of eukaryotic cells. Nuclear proteins include proteins of the nuclear matrix, transport system of the nucleus, and transcription factors. The latter are molecules involved in the regulation of gene expression. They can play a role in the formation of various pathologies, including tumors [22]. In the context of promyelocytic leukemia, the role of nuclear proteins as the key regulators of cell fate suggests that studies of nuclear proteome is a promising field for the search of potential targets for new drugs [25].

We performed comparative liquid chromatography mass spectrometry of nuclear and cytosolic fractions of HL-60 cells at different stages of their ATRAinduced differentiation $(0,3,24$, and $96 \mathrm{~h}$ from the start of the experiment). A total of 1162 proteins (at least by two peptides) were identified. The analysis of mass spectrometry data revealed 172 differentially expressed proteins in the cytosolic fraction (FDR $<10^{-}$ $\left.{ }^{6}\right)$ and 46 proteins $\mathrm{FDR}<10^{-6}$ ) in the nuclear fraction (comparison in all time points). Heat maps reflecting 

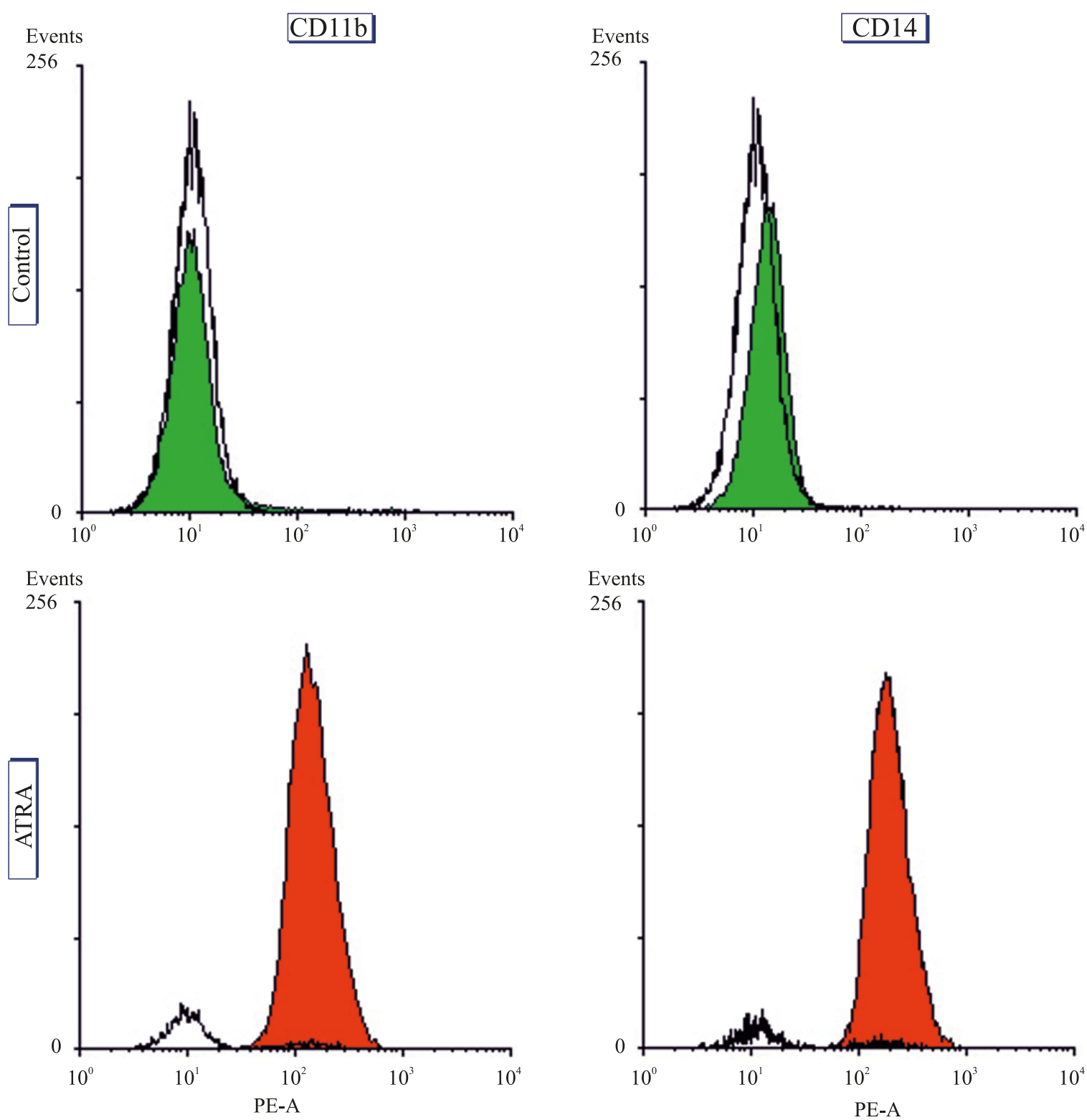

Fig. 2. Changes in the expression of CD11b and CD14 in HL-60 cells after 96-h culturing in the presence of $50 \mu M$ ATRA. Abscissa: fluorescence intensity reflecting the expression of surface marker; ordinate: number of events (cells). Isotypical control is shown by black line.

changes in the gene expression are presented in Figures 3 and 4.

Differentially expressed proteins of nuclear fraction. In the analysis of protein expression in nuclear fractions two main clusters can be isolated in all time points: by $96 \mathrm{~h}$ of cell differentiation, expression of 31 proteins increased under the action of ATRA and expression of 5 proteins decreased (Table 1).

Among the proteins whose content increased, special attention deserved SRSF1 (serine/arginine-rich splicing factor 1), SARS protein (serine tRNA-ligase) that interacts with VEGFA promoter in the nucleus preventing its binding to the proto-oncogene c-ICC [14], protein CLIC1 (chloride intracellular channel protein 1) involved in the regulation of the cell cycle [21], and ALOX5AP protein involved in the synthesis of leukotrienes [6]. According to the Uniprot database annotation, these proteins are located in the nucleus or its membrane.

Among proteins whose content, on the contrary, decreased, protymosin alpha (PTMA) involved in the functioning of the immune system, SND1 protein (Staphylococcal nuclease domain-containing protein 1), a phase transcription factor that regulates STAT6, MYB, and EBNA2 [19], and DNA- and RNA-binding protein NONO (Non-POU domain-containing octamer-binding protein) capable of regulating transcription [15] are worthy of note. According to the 


\section{$a$}
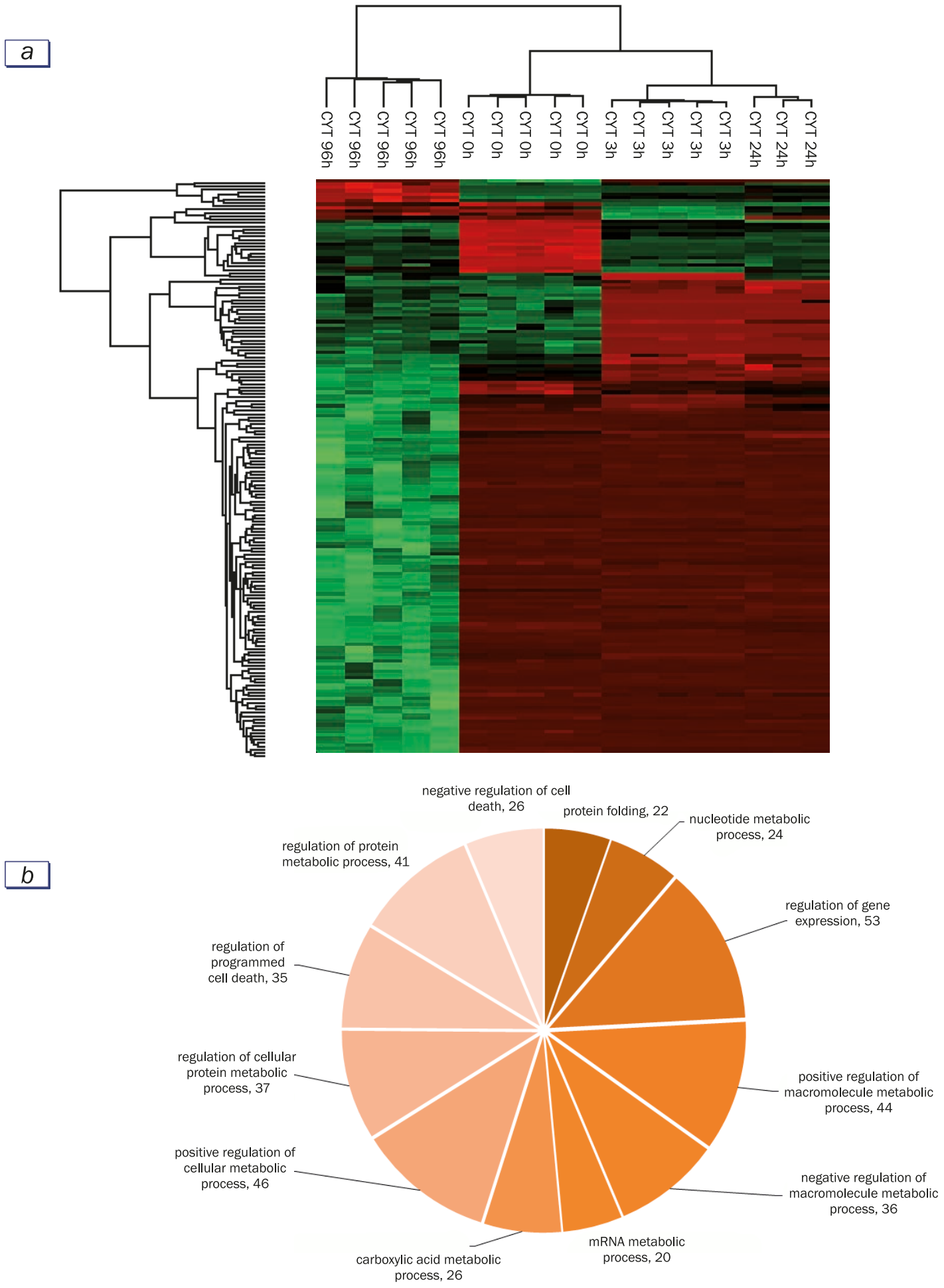

Fig. 3. Differentially expressed proteins of cytosolic fraction: 172 proteins ( $F C>3$, multiple-sample tests ANOVA, FDR=0.0002) (a), functional classification of differentially expressed proteins of cytosol fraction according to GeneOntology database (Biological processes, minimal hits per group $=20, p=0.005)(b)$.

Uniprot database, these proteins are located in the nucleus.

Proteins whose content uniquely varies at different stages of differentiation (Fig. 5). The results of pairwise comparison of the data of mass spectro- metric analysis of samples obtained at each time point with the control are presented in Table 2 . In $3 \mathrm{~h}$ after the addition of ATRA, the content of 16 proteins in the nuclear fraction, including regulators of alternative splicing, DNA repair and apoptosis, changed by more 

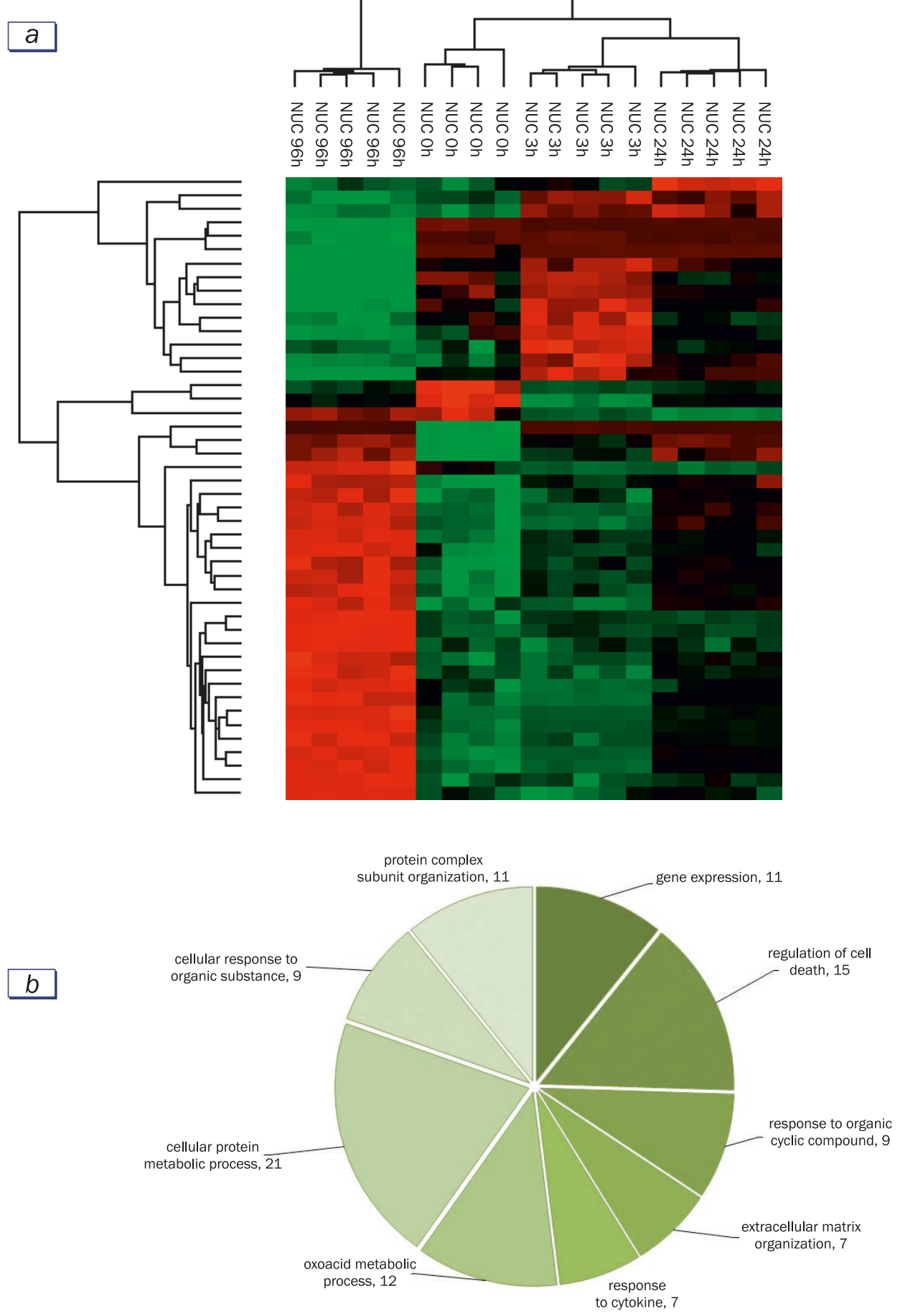

Fig. 4. Differentially expressed proteins of the nuclear fraction: 46 proteins (FC>3, multiple-sample tests ANOVA, FDR=0.0002) (a), functional classification of differentially expressed proteins of the nuclear fraction according to GeneOntology database (Biological processes, minimal hits per group $=20, p=0.005)(b)$.

than 3 times in comparison with the control. According to the Uniprot 13 database annotation, these proteins were located in the nucleus. Of particular interest is protein UBE2V1 (CROC1) mediating activation of C-Fos proto-oncogene transcription [13]. It is involved in DNA reparation and affects cell cycle and differen- tiation. This protein is also involved in activation of NF- $\kappa$ B mediated by IL- $1 \beta$, TNF, TRAF6, and TRAF 2 . In $24 \mathrm{~h}$ after the start of differentiation, 9 unique differentially expressed proteins were revealed in the nucleus, including nucleotide exchange factor (BAG2), deubiquitinylation regulator (SHMT2), and 
TABLE 1. Nuclear Fraction Proteins whose Content Differed from the Control at All Time Points of ATRA-Induced Differentiation of HL-60 Cells

\begin{tabular}{|c|c|c|c|}
\hline Protein & AN Uniprot & Gene & ANOVA $p$-value \\
\hline \multicolumn{4}{|l|}{ Increase in protein content by $96 \mathrm{~h}$} \\
\hline Staphylococcal nuclease domain-containing protein 1 & Q7KZF4 & SND1 & $1.21 \times 10^{-8}$ \\
\hline Heat shock protein HSP 90-beta & P08238 & HSP90AB1 & $1.27 \times 10^{-8}$ \\
\hline Prothymosin alpha & P06454 & PTMA & $2.56 \times 10^{-9}$ \\
\hline $60 S$ ribosomal protein L3 & P39023 & RPL3 & $1.10 \times 10^{-13}$ \\
\hline Eukaryotic translation initiation factor 3 subunit I & Q13347 & EIF3I & $3.29 \times 10^{-9}$ \\
\hline Eukaryotic translation initiation factor 4 gamma 1 & Q04637 & EIF4G1 & $2.59 \times 10^{-10}$ \\
\hline Non-POU domain-containing octamer-binding protein & Q15233 & NONO & $5.27 \times 10^{-9}$ \\
\hline S-adenosylmethionine synthase isoform type-2 & P31153 & MAT2A & $2.82 \times 10^{-8}$ \\
\hline Elongation factor 2 & P13639 & EEF2 & $6.04 \times 10^{-10}$ \\
\hline Multifunctional protein ADE2 & P22234 & PAICS & $6.39 \times 10^{-9}$ \\
\hline L-lactate dehydrogenase A chain & P00338 & $\angle D H A$ & $2.29 \times 10^{-8}$ \\
\hline Polypyrimidine tract-binding protein 1 & P26599 & PTBP1 & $4.10 \times 10^{-9}$ \\
\hline Glyceraldehyde-3-phosphate dehydrogenase & P04406 & GAPDH & $1.04 \times 10^{-8}$ \\
\hline Elongation factor 1-beta & P24534 & EEF1B2 & $3.92 \times 10^{-8}$ \\
\hline Deoxyuridine 5-triphosphate nucleotidohydrolase, mitochondrial & P33316 & DUT & $5.66 \times 10^{-9}$ \\
\hline \multicolumn{4}{|l|}{ Decrease in protein content by $96 \mathrm{~h}$} \\
\hline $40 S$ ribosomal protein S8 & P62241 & RPS8 & $1.39 \times 10^{-9}$ \\
\hline Serine/arginine-rich splicing factor 1 & Q07955 & SRSF1 & $3.21 \times 10^{-12}$ \\
\hline Histone $\mathrm{H} 4$ & P62805 & HIST1H4A & $2.22 \times 10^{-8}$ \\
\hline Serine - tRNA ligase, cytoplasmic & P49591 & SARS & $9.42 \times 10^{-13}$ \\
\hline Moesin & P26038 & MSN & $6.50 \times 10^{-11}$ \\
\hline Tyrosine - tRNA ligase & P54577 & YARS & $8.70 \times 10^{-10}$ \\
\hline Glutamate dehydrogenase 1 & P00367 & GLUD1 & $9.19 \times 10^{-10}$ \\
\hline Endoplasmin & P14625 & HSP90B1 & $4.68 \times 10^{-9}$ \\
\hline Cofilin-1 & P23528 & CFL1 & $6.93 \times 10^{-9}$ \\
\hline Peptidyl-prolyl cis-trans isomerase B & P23284 & $P P I B$ & $9.29 \times 10^{-10}$ \\
\hline Galectin-1 & P09382 & LGALS1 & $3.47 \times 10^{-10}$ \\
\hline Protein disulfide-isomerase & P07237 & $P 4 H B$ & $6.63 \times 10^{-10}$ \\
\hline Annexin A1 & P04083 & $A N X A 1$ & $1.94 \times 10^{-9}$ \\
\hline Protein disulfide-isomerase A4 & P13667 & PDIA4 & $2.13 \times 10^{-8}$ \\
\hline Plastin-2 & P13796 & $L C P 1$ & $8.18 \times 10^{-10}$ \\
\hline Chloride intracellular channel protein 1 & 000299 & CLIC1 & $1.26 \times 10^{-8}$ \\
\hline Coactosin-like protein & Q14019 & COTL1 & $7.51 \times 10^{-11}$ \\
\hline Malate dehydrogenase, mitochondrial & P40926 & $\mathrm{MDH} 2$ & $5.64 \times 10^{-13}$ \\
\hline NAD-dependent malic enzyme, mitochondrial & P23368 & ME2 & $2.16 \times 10^{-14}$ \\
\hline Intercellular adhesion molecule 1 & P05362 & ICAM1 & $4.50 \times 10^{-10}$ \\
\hline Synaptic vesicle membrane protein VAT- 1 homolog & Q99536 & VAT1 & $4.50 \times 10^{-9}$ \\
\hline Phosphoserine aminotransferase & Q9Y617 & PSAT1 & $2.98 \times 10^{-11}$ \\
\hline $10 \mathrm{kDa}$ heat shock protein, mitochondrial & P61604 & HSPE1 & $2.39 \times 10^{-9}$ \\
\hline Annexin A6 & P08133 & $A N X A 6$ & $4.42 \times 10^{-11}$ \\
\hline 6-phosphogluconate dehydrogenase, decarboxylating & P52209 & $P G D$ & $2.08 \times 10^{-12}$ \\
\hline 78 kDa glucose-regulated protein & P11021 & HSPA5 & $1.33 \times 10^{-14}$ \\
\hline Annexin A5 & P08758 & ANXA5 & $2.25 \times 10^{-12}$ \\
\hline Protein disulfide-isomerase $\mathrm{A} 3$ & P30101 & PDIA3 & $4.15 \times 10^{-14}$ \\
\hline Cathepsin D & P07339 & CTSD & $2.67 \times 10^{-14}$ \\
\hline Metalloproteinase inhibitor 1 & P01033 & TIMP1 & $5.75 \times 10^{-10}$ \\
\hline Arachidonate 5-lipoxygenase-activating protein & P20292 & ALOX5AP & $8.32 \times 10^{-9}$ \\
\hline
\end{tabular}


TABLE 2. Nuclear Fraction Proteins Whose Content Significantly Differed from the Control Only in One Time Point: 3, 24, or $96 \mathrm{~h}$ (Proteins Identified by at Least Two Proteotypic Peptides) $(p<0.01)$

\begin{tabular}{|c|c|c|c|c|}
\hline Protein & AN Uniprot & Gene & FC & $\begin{array}{l}\text { Intracellular localization, } \\
\text { Uniprot database annotation }\end{array}$ \\
\hline \multicolumn{5}{|l|}{$3 \mathrm{~h}$ vs. $\mathrm{O} h$} \\
\hline $\begin{array}{l}\text { Probable } 28 S \text { rRNA (cytosine(4447)-C(5))- } \\
\text { methyltransferase }\end{array}$ & P46087 & NOP2 & 0.2 & Nucleus \\
\hline $40 S$ ribosomal protein $\mathrm{S} 10$ & P46783 & RPS10 & 0.3 & Nucleus \\
\hline $\begin{array}{l}\text { Eukaryotic translation initiation factor } 3 \\
\text { subunit } \mathrm{E}\end{array}$ & P60228 & EIF3E & 3.3 & Nucleus (PML bodies), cytoplasm \\
\hline Acylamino-acid-releasing enzyme & P13798 & APEH & 3.3 & Cytoplasm \\
\hline Methylosome subunit plCln & P54105 & CLNS1A & 3.9 & Nucleus (PML bodies) \\
\hline $\mathrm{N}$-alpha-acetyltransferase 50 & Q9GZZ1 & NAA50 & 3.9 & Nucleus \\
\hline Small nuclear ribonucleoprotein G; & P62308 & SNRPG & 4.0 & Nucleus, cytoplasm \\
\hline Ubiquitin-conjugating enzyme E2 variant 1 & Q13404 & UBE2V1 & 4.4 & Nucleus \\
\hline Protein arginine $\mathrm{N}$-methyltransferase 1 & Q99873 & PRMT1 & 5.3 & Nucleus, cytoplasm \\
\hline Myeloblastin & P24158 & PRTN3 & 5.7 & Secretory protein \\
\hline Proteasome subunit beta type- 1 & P20618 & PSMB1 & 7.3 & Nucleus, cytoplasm \\
\hline Heterogeneous nuclear ribonucleoprotein $\mathrm{K}$ & P61978 & HNRNPK & 7.3 & Nucleus, nucleoplasm \\
\hline $\begin{array}{l}\text { Eukaryotic translation initiation factor } 3 \\
\text { subunit B }\end{array}$ & P55884 & EIF3B & 7.8 & Cytoplasm \\
\hline Superoxide dismutase [Cu-Zn] & P00441 & SOD1 & 8.7 & Nucleus, mitochondria, cytoplasm \\
\hline RNA-binding protein 8A & Q9Y5S9 & $R B M 8 A$ & 10.7 & Nucleus \\
\hline Translin & Q15631 & TSN & 13.7 & Nucleus, cytoplasm \\
\hline \multicolumn{5}{|l|}{$24 h$ vs. $0 h$} \\
\hline $\begin{array}{l}\text { BAG family molecular chaperone regulator } \\
2\end{array}$ & O95816 & BAG2 & 0.5 & Cytoplasm \\
\hline Serine hydroxymethyltransferase & P34897 & SHMT2 & 2.2 & Nucleus, mitochondria, cytoplasm \\
\hline Cytosolic non-specific dipeptidase & Q96KP4 & CNDP2 & 2.2 & Cytoplasm \\
\hline GTP-binding protein SAR1a & Q9NR31 & SAR1A & 2.6 & $\begin{array}{l}\text { Endoplasmic reticulum, } \\
\text { Golgi complex }\end{array}$ \\
\hline $\begin{array}{l}\text { Eukaryotic translation initiation factor } 3 \\
\text { subunit } \mathrm{H}\end{array}$ & 015372 & EIF3H & 3.4 & Cytoplasm \\
\hline Farnesyl pyrophosphate synthase & P14324 & FDPS & 3.5 & Cytoplasm \\
\hline Eukaryotic translation initiation factor 1 & P41567 & EIF1 & 3.5 & Nucleus, cytoplasm \\
\hline Lymphocyte cytosolic protein 2 & Q13094 & LCP2 & 4.6 & Cytoplasm \\
\hline $\begin{array}{l}\text { UTP - glucose-1-phosphate uridylyltrans- } \\
\text { ferase }\end{array}$ & Q16851 & UGP2 & 5.2 & Cytoplasm \\
\hline \multicolumn{5}{|l|}{$96 h$ vs. $0 h$} \\
\hline $60 S$ ribosomal protein $\mathrm{L} 11$ & P62913 & $R P L 11$ & 0.04 & Nucleus \\
\hline DNA replication licensing factor $\mathrm{MCM} 3$ & P25205 & МСМЗ & 0.05 & Nucleus \\
\hline DNA replication licensing factor MCM4 & P33991 & MCM4 & 0.07 & Nucleus \\
\hline DNA replication licensing factor MCM7 & P33993 & MCM7 & 0.07 & Nucleus \\
\hline DNA replication licensing factor MCM5 & P33992 & MCM5 & 0.08 & Nucleus, cytosol \\
\hline ATP-dependent RNA helicase DDX18 & Q9NVP1 & $D D \times 18$ & 0.09 & Nucleus, chromosomes \\
\hline DNA replication licensing factor MCM6 & Q14566 & MCM6 & 0.09 & Nucleus \\
\hline
\end{tabular}


TABLE 2.

\begin{tabular}{|c|c|c|c|c|}
\hline Protein & AN Uniprot & Gene & FC & $\begin{array}{l}\text { Intracellular localization, } \\
\text { Uniprot database annotation }\end{array}$ \\
\hline $60 S$ ribosomal protein L10 & P27635 & RPL10 & 0.10 & $\begin{array}{l}\text { Nucleus, cytosol, } \\
\text { endoplasmic reticulum }\end{array}$ \\
\hline $60 S$ acidic ribosomal protein $\mathrm{P} 1$ & P05386 & $R P L P 1$ & 0.10 & Cytosol, exosomes \\
\hline RNA-binding protein FUS & P35637 & FUS & 0.10 & Nucleus \\
\hline $\begin{array}{l}\text { Nucleolar and coiled-body phosphoprotein } \\
1\end{array}$ & Q14978 & NOLC1 & 0.10 & Nucleus \\
\hline 14-3-3 protein eta & Q04917 & YWHAH & 0.10 & $\begin{array}{l}\text { Cytosol, exosomes, mitochondria, } \\
\text { plasma membrane }\end{array}$ \\
\hline Peroxisomal multifunctional enzyme type 2 & P51659 & HSD17B4 & 0.11 & Peroxisomes \\
\hline Cytochrome c & P99999 & CYCS & 0.11 & Mitochondria \\
\hline Nucleolar RNA helicase 2 & Q9NR30 & $D D \times 21$ & 0.12 & Nucleus \\
\hline DNA replication licensing factor $\mathrm{MCM} 2$ & P49736 & MCM2 & 0.13 & Nucleus \\
\hline $\begin{array}{l}\text { Eukaryotic translation initiation factor } 3 \\
\text { subunit I }\end{array}$ & Q13347 & EIF3I & 0.14 & Cytoplasm \\
\hline Hsc70-interacting protein & P50502 & ST13 & 0.14 & Cytoplasm \\
\hline FACT complex subunit SSRP1 & Q08945 & SSRP1 & 0.14 & Nucleus, chromosomes \\
\hline DAZ-associated protein 1 & Q96EP5 & $D A Z A P 1$ & 0.14 & Nucleus \\
\hline Splicing factor $3 \mathrm{~A}$ subunit 3 & Q12874 & SF3A3 & 0.15 & Nucleus (nuclear speckles) \\
\hline Splicing factor, proline- and glutamine-rich & P23246 & $S F P Q$ & 0.16 & Nucleus, nuclear matrix \\
\hline $60 S$ ribosomal protein L14 & P50914 & RPL14 & 0.17 & $\begin{array}{l}\text { Cytosol, exosomes, } \\
\text { plasma membrane }\end{array}$ \\
\hline 40S ribosomal protein S28 & P62857 & RPS28 & 0.17 & Cytosol \\
\hline $40 S$ ribosomal protein $S 27$ & P42677 & RPS27 & 0.17 & Nucleus, cytosol \\
\hline $60 S$ ribosomal protein L19 & P84098 & RPL19 & 0.17 & Cytosol \\
\hline Serine/threonine-protein kinase VRK1 & Q99986 & VRK1 & 0.18 & Nucleus \\
\hline $\begin{array}{l}\text { DNA-dependent protein kinase catalytic } \\
\text { subunit }\end{array}$ & P78527 & $P R K D C$ & 0.19 & Nucleus \\
\hline Poly [ADP-ribose] polymerase 1 & P09874 & PARP1 & 0.19 & Nucleus \\
\hline $40 S$ ribosomal protein $\mathrm{S} 17$ & P08708 & RPS17 & 0.20 & $\begin{array}{l}\text { Cytosol, extracellular matrix, } \\
\text { nucleoplasm }\end{array}$ \\
\hline DNA topoisomerase 2-beta & Q02880 & TOP2B & 0.20 & Nucleus \\
\hline Unconventional myosin-Ig & B0I1T2 & MYO1G & 0.20 & Plasma membrane \\
\hline Nucleolar transcription factor 1 & P17480 & UBTF & 0.21 & Nucleus \\
\hline Transformer-2 protein homolog beta & P62995 & TRA2B & 0.21 & Nucleus \\
\hline Heterogeneous nuclear ribonucleoprotein L & P14866 & HNRNPL & 0.21 & Nucleus \\
\hline RNA-binding protein EWS & Q01844 & EWSR1 & 0.21 & $\begin{array}{l}\text { Nucleus, cytoplasm, } \\
\text { plasma membrane }\end{array}$ \\
\hline Beta-adrenergic receptor kinase 1 & P25098 & $A D R B K 1$ & 0.22 & Cytoplasm, plasma membrane \\
\hline Eukaryotic translation initiation factor $4 \mathrm{~B}$ & P23588 & EIF4B & 0.22 & Cytosol \\
\hline Paraspeckle component 1 & Q8WXF1 & PSPC1 & 0.22 & Nucleus \\
\hline Receptor of activated protein C kinase 1 & P63244 & GNB2L 1 & 0.22 & $\begin{array}{l}\text { Nucleus, cytoplasm, } \\
\text { plasma membrane }\end{array}$ \\
\hline Septin-6 & Q14141 & SEPT6 & 0.23 & Cytoplasm \\
\hline Mitotic checkpoint protein BUB3 & O43684 & BUB3 & 0.24 & Nucleus \\
\hline
\end{tabular}


TABLE 2.

\begin{tabular}{|c|c|c|c|c|}
\hline Protein & AN Uniprot & Gene & FC & $\begin{array}{l}\text { Intracellular localization, } \\
\text { Uniprot database annotation }\end{array}$ \\
\hline $\begin{array}{l}\text { Trifunctional purine biosynthetic protein } \\
\text { adenosine-3 }\end{array}$ & P22102 & GART & 0.25 & Cytosol, exosomes \\
\hline Endothelial differentiation-related factor 1 & 060869 & EDF1 & 0.25 & Nucleus \\
\hline $\begin{array}{l}\text { Eukaryotic translation initiation factor } 2 \\
\text { subunit } 2\end{array}$ & P20042 & EIF2S2 & 0.25 & Cytoplasm \\
\hline General transcription factor II-I & P78347 & GTF2I & 0.25 & Nucleus \\
\hline UPF0568 protein C14orf166 & Q9Y224 & C14orf166 & 0.26 & Nucleus, cytoplasm \\
\hline RNA-binding motif protein, $\mathrm{X}$ chromosome & P38159 & $R B M X$ & 0.26 & Nucleus \\
\hline $\begin{array}{l}\text { Replication protein A } 70 \text { kDa DNA-binding } \\
\text { subunit }\end{array}$ & P27694 & RPA1 & 0.27 & Nucleus \\
\hline Spectrin beta chain, non-erythrocytic 1 & Q01082 & SPTBN1 & 0.28 & Cytoskeleton \\
\hline Nucleoplasmin-3 & O75607 & NPM3 & 0.29 & Nucleus \\
\hline $40 S$ ribosomal protein S3 & P23396 & RPS3 & 0.29 & Nucleus, cytoplasm, mitochondria \\
\hline $\begin{array}{l}\text { Eukaryotic translation initiation factor } 4 \\
\text { gamma } 1\end{array}$ & Q04637 & EIF4G1 & 0.29 & Nucleus, cytoplasm \\
\hline $\begin{array}{l}\text { Heterogeneous nuclear ribonucleoprotein } \\
\text { A1 }\end{array}$ & P09651 & HNRNPA1 & 0.29 & Nucleus, cytoplasm \\
\hline $\begin{array}{l}116 \mathrm{kDa} \text { U5 small nuclear ribonucleoprotein } \\
\text { component }\end{array}$ & Q15029 & EFTUD2 & 0.29 & Nucleus \\
\hline $40 S$ ribosomal protein $\mathrm{S} 12$ & P25398 & RPS12 & 0.29 & Cytoplasm \\
\hline Polyadenylate-binding protein 1 & P11940 & $P A B P C 1$ & 0.31 & Nucleus, cytoplasm \\
\hline $\begin{array}{l}\text { S-adenosylmethionine synthase isoform } \\
\text { type-2 }\end{array}$ & P31153 & MAT2A & 0.31 & Cytoplasm \\
\hline $\begin{array}{l}\text { Structural maintenance of chromosomes } \\
\text { flexible hinge domain-containing protein } 1\end{array}$ & A6NHR9 & SMCHD1 & 0.32 & Nucleus \\
\hline Aspartate--tRNA ligase, mitochondrial & Q6PI48 & DARS2 & 0.32 & Mitochondria \\
\hline Pre-mRNA-processing-splicing factor 8 & Q6P2Q9 & PRPF8 & 0.33 & Nucleus \\
\hline $40 S$ ribosomal protein S5 & P46782 & RPS5 & 0.34 & Nucleoplasm, cytoplasm, exosomes \\
\hline $10 \mathrm{kDa}$ heat shock protein, mitochondrial & P61604 & HSPE1 & 3.01 & Mitochondria \\
\hline Asparagine-tRNA ligase, cytoplasmic & O43776 & NARS & 3.03 & Cytoplasm \\
\hline Histone H1.5 & P16401 & HIST1H1B & 3.03 & Nucleus \\
\hline Transaldolase & P37837 & TALDO1 & 3.05 & Cytoplasm \\
\hline Peroxiredoxin-5, mitochondrial & P30044 & PRDX5 & 3.07 & Mitochondria, peroxisomes \\
\hline $\begin{array}{l}\text { Malate dehydrogenase, mitochondrial; } \\
\text { Malate dehydrogenase }\end{array}$ & P40926 & $\mathrm{MDH} 2$ & 3.16 & Mitochondria \\
\hline Talin-1 & Q9Y490 & $T L N 1$ & 3.16 & Cytoplasm \\
\hline Intercellular adhesion molecule 1 & P05362 & ICAM1 & 3.21 & Plasma membrane \\
\hline $\begin{array}{l}\text { Single-stranded DNA-binding protein, } \\
\text { mitochondrial }\end{array}$ & Q04837 & $S S B P 1$ & 3.38 & Mitochondria \\
\hline $\begin{array}{l}\text { NAD-dependent malic enzyme, } \\
\text { mitochondrial }\end{array}$ & P23368 & ME2 & 3.41 & Mitochondria \\
\hline Protein FAM49B & Q9NUQ9 & FAM49B & 3.42 & Plasma membrane \\
\hline Annexin A11 & P50995 & ANXA11 & 3.54 & Nucleus, cytoplasm \\
\hline Protein canopy homolog 2 & Q9Y2B0 & CNPY2 & 3.97 & Nucleus, cytoplasm \\
\hline Protein canopy homolog 2 & Q9Y2B0 & CNPY2 & 3.97 & Nucleus, cytoplasm \\
\hline
\end{tabular}


TABLE 2.

\begin{tabular}{|c|c|c|c|c|}
\hline Protein & AN Uniprot & Gene & $\mathrm{FC}$ & $\begin{array}{l}\text { Intracellular localization, } \\
\text { Uniprot database annotation }\end{array}$ \\
\hline ERO1-like protein alpha & Q96HE7 & ERO1L & 4.05 & Endoplasmic reticulum \\
\hline Protein S100-A9 & P06702 & S100A9 & 4.11 & $\begin{array}{l}\text { Nucleus, cytoplasm, } \\
\text { microvillus membrane }\end{array}$ \\
\hline Annexin A4; Annexin & P09525 & ANXA4 & 4.11 & Nucleus, exosomes \\
\hline $\begin{array}{l}\text { V-type proton ATPase subunit B, } \\
\text { brain isoform }\end{array}$ & P21281 & ATP6V1B2 & 4.47 & Endosomes \\
\hline Hexokinase-1 & P19367 & $H K 1$ & 4.56 & Mitochondria \\
\hline Pyruvate kinase PKM & P14618 & $P K M$ & 4.85 & $\begin{array}{l}\text { Nucleus (translocation in response } \\
\text { to apoptotic stimulus), cytoplasm }\end{array}$ \\
\hline Fructose-1,6-bisphosphatase 1 & P09467 & FBP1 & 5.24 & Mitochondria \\
\hline F-actin-capping protein subunit alpha-2 & P47755 & CAPZA2 & 5.39 & Cytoskeleton, cytoplasm, exosomes \\
\hline $\begin{array}{l}\text { Protein-tyrosine-phosphatase; receptor-type } \\
\text { tyrosine-protein phosphatase C }\end{array}$ & P08575 & PTPRC & 5.45 & Plasma membrane \\
\hline Leukocyte elastase inhibitor & P30740 & SERPINB 1 & 5.54 & Cytoplasm \\
\hline $\begin{array}{l}\text { Protein-glutamine gamma-glutamyltransfer- } \\
\text { ase } 2\end{array}$ & P21980 & TGM2 & 5.58 & Cytoplasm, mitochondria \\
\hline $\begin{array}{l}\text { Cytochrome b-c1 complex subunit } 1 \text {, mito- } \\
\text { chondrial }\end{array}$ & P31930 & UQCRC1 & 5.62 & Mitochondria \\
\hline Tropomyosin alpha-4 chain & P67936 & TPM4 & 5.64 & Cytoskeleton \\
\hline Proteasome subunit beta type- 8 & P28062 & PSMB8 & 5.72 & Nucleus \\
\hline Core histone macro-H2A. 1 & O75367 & H2AFY & 6.01 & Nucleus \\
\hline Nicotinamide phosphoribosyltransferase & P43490 & NAMPT & 6.05 & Nucleus \\
\hline Pleckstrin & P08567 & PLEK & 6.10 & Cytoplasm \\
\hline Lactoylglutathione lyase & Q04760 & GLO1 & 6.15 & Nucleus, cytoplasm \\
\hline Prostaglandin E synthase 3 & Q15185 & PTGES3 & 6.35 & Cytoplasm \\
\hline Dipeptidyl peptidase 3 & Q9NY33 & DPP3 & 6.44 & Cytoplasm \\
\hline Interleukin-8 & P10145 & CXCL8 & 6.46 & Secretory protein \\
\hline Protein S100-P & P25815 & S100P & 6.85 & $\begin{array}{l}\text { Nucleus, cytoplasm, microvillus } \\
\text { membrane }\end{array}$ \\
\hline Glutathione S-transferase omega-1 & P78417 & GSTO1 & 6.92 & Cytoplasm \\
\hline V-type proton ATPase subunit G 1 & O75348 & ATP6V1G1 & 7.10 & Plasma membrane, exosomes \\
\hline $\begin{array}{l}\text { BTB/POZ domain-containing protein } \\
\text { KCTD12 }\end{array}$ & Q96CX2 & KCTD12 & 7.27 & Plasma membrane \\
\hline Glucose-6-phosphate 1-dehydrogenase & P11413 & G6PD & 8.85 & Cytoplasm, exosomes \\
\hline Protein S100-A8 & P05109 & S100A8 & 8.89 & $\begin{array}{l}\text { Plasma membrane, secretory } \\
\text { protein, cytoskeleton }\end{array}$ \\
\hline Glutathione reductase, mitochondrial & P00390 & GSR & 9.09 & Mitochondria \\
\hline $\begin{array}{l}\text { Arachidonate 5-lipoxygenase-activating } \\
\text { protein }\end{array}$ & P20292 & ALOX5AP & 9.29 & Mitochondria \\
\hline Histone $\mathrm{H} 1 \mathrm{x}$ & Q92522 & $H 1 F X$ & 9.90 & Nucleus \\
\hline $\begin{array}{l}\text { Tryptophan-tRNA ligase, cytoplasmic; } \\
\text { T1-TrpRS;T2-TrpRS }\end{array}$ & P23381 & WARS & 9.90 & Cytoplasm \\
\hline Plasminogen activator inhibitor 2 & P05120 & SERPINB2 & 9.99 & Secretory protein \\
\hline C-C motif chemokine 2 & P13500 & CCL2 & 10.36 & Secretory protein \\
\hline Metalloproteinase inhibitor 1 & P01033 & TIMP1 & 20.12 & Secretory protein \\
\hline
\end{tabular}




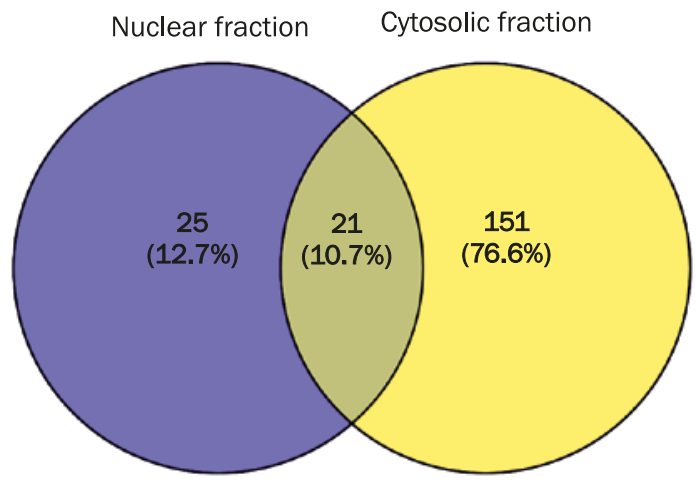

Fig. 5. Venn's diagram for differentially expressed proteins of nuclear and cytosolic fractions of HL-60 cells. The diagram shows the number of unique and common proteins for both fractions. The intersection between the fractions of differentially expressed proteins includes 21 proteins

MAPK signal pathway activator (CNDP2). The latter was shown to participate in the development of gastric cancer [27].

In $96 \mathrm{~h}, 110$ proteins were uniquely differentially expressed in the nuclear fraction; 17 of them are involved in the functioning of the immune system: S100P, S100A8, SFPQ, S100A9, PKM1, CAPZA2, SERPINB1, CXCL8, ICAM1, CCL2, ANXA1, PRKDC, PSMB8, MYO1G, RPS17, PSPC1, and PTPRC (GO annotation, categories Biological process; Uniprot database). Thus, the content of CXCL8, a factor involved in neutrophil activation [20], was elevated by more than 6 times $(\mathrm{FC}=6.46)$. Proteins SFPQ and PSPC1 form a heterodimer that is a component of the nuclear paraspeckles [29]. We observed parallel reduction in the content of both components of the heterodimer (FC SFPQ $=0.16$ and FC PSPC1 $=0.22$ ). Interestingly, the content of proteins involved in DNA replication and repair (MCM3, MCM4, MCM7, MCM5, DDX18, MCM6, FUS, NOLC1, DDX21, MCM2, SSRP1, PRKDC, PARP1, TOP2B, BUB3, and RPA1) was also reduced by more than 5 times. By the end of differentiation, proteins exhibiting activity of transcription factors were detected in the nuclei: UBTF ( $\mathrm{FC}=0.21), \mathrm{EDF} 1(\mathrm{FC}=0.25), \mathrm{GTF} 2 \mathrm{I}$ $(\mathrm{FC}=0.25), \operatorname{RBMX}(\mathrm{FC}=0.25)$, and $\mathrm{FUS}(\mathrm{FC}=0.1)$.

Our results confirm the general hypothesis that ATRA-induced differentiation of HL-60 cells is accompanied by significant changes in the content of various proteins involved in the regulation of gene expression in the nucleoplasm of these cells. The use of high-resolution comparative chromatography-mass spectrometry allowed us to identify some proteins that potentially can modulate development of tumors, including OPL. We referred to protein descriptions in Uniprot database, one of the most relevant protein databases. Deciphering of the mechanisms of action of the detected functionally active protein molecules as well as profound study of proteins, whose functions are currently unknown were beyond the scope of our study. Nevertheless, our results are of utmost interest, because they help to narrow the search for potential molecular targets for targeted anti-leukemia therapy.

The study was supported by the Russian Science Foundation (grant No. 17-75-10201) with the use of the Human Proteome Common Use Center (Institute of Biomedical Chemistry) supported by the Ministry of Education and Science of the Russian Federation (unique project identifier RFMEFI62117X0017).

\section{REFERENCES}

1. Álvarez-Chaver P, De Chiara L, Martínez-Zorzano VS. Proteomic profiling for colorectal cancer biomarker discovery. Methods Mol. Biol. 2018;1765:241-269.

2. Birnie GD. The HL60 cell line: a model system for studying human myeloid cell differentiation. Br. J. Cancer Suppl. 1988;9:41-45.

3. Concolino A, Olivo E, Tammè L, Fiumara CV, De Angelis MT, Quaresima B, Agosti V, Costanzo FS, Cuda G, Scumaci D. Proteomics analysis to assess the role of mitochondria in BRCA1-mediated breast tumorigenesis. Proteomes. 2018;6(2). pii: E16. doi: 10.3390/proteomes6020016.

4. Coombs CC, Tavakkoli M, Tallman MS. Acute promyelocytic leukemia: where did we start, where are we now, and the future. Blood Cancer J. 2015;5:e304. doi: 10.1038/bcj.2015.25.

5. Cox J, Hein MY, Luber CA, Paron I, Nagaraj N, Mann M. Accurate proteome-wide label-free quantification by delayed normalization and maximal peptide ratio extraction, termed MaxLFQ. Mol. Cell. Proteomics. 2014;13(9):2513-2526.

6. Dixon RA, Diehl RE, Opas E, Rands E, Vickers PJ, Evans JF, Gillard JW, Miller DK. Requirement of a 5-lipoxygenase-activating protein for leukotriene synthesis. Nature. 1990;343:282284.

7. Hong C, An S, Son M, Hong SS, Lee DH, Lee C. In-vitro cell tests using doxorubicin-loaded polymeric TiO2 nanotubes used for cancer photothermotherapy. Anticancer Drugs. 2012;23(5):553-560.

8. Huang H, Qin Y, Xu R, You X, Teng R, Yang L, Xu M, Liu H. Combination therapy with arsenic trioxide, all-trans retinoic acid, and chemotherapy in acute promyelocytic leukemia patients with various relapse risks. Leuk. Res. 2012;36(7):841845 .

9. Huang J, Casas Garcia GP, Perugini MA, Fox A, Bond C, Lee M. Crystal structure of a SFPQ/PSPC1 heterodimer provides insights into preferential heterodimerization of human DBHS family proteins. J. Biol. Chem. 2018. Mar 12. pii: jbc. RA117.001451. doi: 10.1074/jbc.RA117.001451.

10. Iland HJ, Bradstock K, Supple SG, Catalano A, Collins M, Hertzberg M, Browett P, Grigg A, Firkin F, Hugman A, Reynolds J, Di Iulio J, Tiley C, Taylor K, Filshie R, Seldon M, Taper J, Szer J, Moore J, Bashford J, Seymour JF; Australasian Leukaemia and Lymphoma Group. All-trans-retinoic acid, idarubicin, and IV arsenic trioxide as initial therapy in acute promyelocytic leukemia (APML4). Blood. 2012;120(8):15701580; quiz 1752.

11. Li T, Ma R, Zhang Y, Mo H, Yang X, Hu S, Wang L, Nova- 
kovic VA, Chen H, Kou J, Bi Y, Yu B, Fang S, Wang J, Zhou J, Shi J. Arsenic trioxide promoting ETosis in acute promyelocytic leukemia through mTOR-regulated autophagy. Cell Death Dis. 2018;9(2):75. doi: 10.1038/s41419-017-0018-3.

12. Reyes-Sebastian J, Montiel-Cervantes LA, Reyes-Maldonado E, Dominguez-Lopez ML, Ortiz-Butron R, Castillo-Alvarez A, Lezama RA. Cell proliferation and inhibition of apoptosis are related to c-Kit activation in leukaemic lymphoblasts. Hematology. 2018;Mar 1:1-10. doi: 10.1080/10245332.2018.1444564.

13. Rothofsky ML, Lin SL. CROC-1 encodes a protein which mediates transcriptional activation of the human FOS promoter. Gene. 1997;195(2):141-149.

14. Shi Y, Xu X, Zhang Q, Fu G, Mo Z, Wang GS, Kishi S, Yang XL. tRNA synthetase counteracts c-Myc to develop functional vasculature. Elife. 2014;3:e02349. doi: 10.7554/eLife.02349.

15. Sewer MB, Nguyen VQ, Huang CJ, Tucker PW, Kagawa N, Waterman MR. Transcriptional activation of human CYP17 in H295R adrenocortical cells depends on complex formation among p54(nrb)/NonO, protein-associated splicing factor, and $\mathrm{SF}-1$, a complex that also participates in repression of transcription. Endocrinology. 2002;143(4):1280-1290.

16. Simicevic J, Schmid AW, Gilardoni PA, Zoller B, Raghav SK, Krier I, Gubelmann C, Lisacek F, Naef F, Moniatte M, Deplancke B. Absolute quantification of transcription factors during cellular differentiation using multiplexed targeted proteomics. Nat. Methods. 2013;10(6):570-576.

17. Takahashi H, Hatta Y, Iriyama N, Hasegawa Y, Uchida H, Nakagawa M, Makishima M, Takeuchi J, Takei M. Induced differentiation of human myeloid leukemia cells into M2 macrophages by combined treatment with retinoic acid and 1alpha,25dihydroxyvitamin D3. PLoS One. 2014;9(11):e113722. doi: 10.1371/journal.pone.0113722.

18. Tasseff R, Jensen HA, Congleton J, Dai D, Rogers KV, Sagar A, Bunaciu RP, Yen A, Varner JD. An effective model of the retinoic acid induced HL-60 differentiation program. Sci. Rep. 2017;7(1):14327. doi: 10.1038/s41598-017-14523-5.

19. Tong X, Drapkin R, Yalamanchili R, Mosialos G, Kieff E. The Epstein-Barr virus nuclear protein 2 acidic domain forms a complex with a novel cellular coactivator that can interact with TFIIE. Mol. Cell. Biol. 1995;15(9):4735-4744.

20. Van Damme J, Rampart M, Conings R, Decock B, Van Osselaer N, Willems J, Billiau A. The neutrophil-activating proteins interleukin 8 and beta-thromboglobulin: in vitro and in vivo comparison of NH2-terminally processed forms. Eur. J. Immunol. 1990;20(9):2113-2118.

21. Valenzuela SM, Mazzanti M, Tonini R, Qiu MR, Warton K, Musgrove EA, Campbell TJ, Breit SN. The nuclear chloride ion channel NCC27 is involved in regulation of the cell cycle. J. Physiol. 2000;529(Pt 3):541-552.

22. Vaquerizas JM, Kummerfeld SK, Teichmann SA, Luscombe NM. A census of human transcription factors: function, expression and evolution. Nat. Rev. Genet. 2009;10(4):252-263.

23. Wang ZY, Chen Z. Acute promyelocytic leukemia: from highly fatal to highly curable. Blood. 2008;111(5):2505-2515.

24. Wiśniewski JR, Zougman A, Nagaraj N, Mann M. Universal sample preparation method for proteome analysis. Nat. Methods. 2009;6(5):359-362.

25. Yao YL, Yang WM. Nuclear proteins: promising targets for cancer drugs. Curr. Cancer Drug Targets. 2005;5(8):595-610.

26. Zhang C, Leng W, Sun C, Lu T, Chen Z, Men X, Wang Y, Wang G, Zhen B, Qin J. Urine proteome profiling predicts lung cancer from control cases and other tumors. EBioMedicine. 2018. Mar 17. pii: S2352-3964(18)30093-8. doi: 10.1016/j. ebiom.2018.03.009.

27. Zhang Z, Miao L, Xin X, Zhang J, Yang S, Miao M, Kong X, Jiao B. Underexpressed CNDP2 participates in gastric cancer growth inhibition through activating the MAPK signaling pathway. Mol. Med. 2014;20):17-28. 